\title{
The Influence of Working Capital Management on Profitability and its Impact on Loan Interest (Empirical Study at: PT. Bringin Karya Sejahtera from 2012-2016)
}

\author{
Endang Afritiani ${ }^{1}$, Bambang Mulyana ${ }^{2}$ \\ \{endang.afritiani@gmail.com ${ }^{1}$, Bambang_0406@yahoo.co.id² \\ Universitas Mercu Buana, Jakarta, Indonesia ${ }^{12}$
}

\begin{abstract}
Companies that have efficient working capital management can improve the company's ability to manage current assets and current liabilities better. When a company has high production capability, the company can provide sufficient funds and capital. With good management of working capital management, it is certainly expected that the company can produce good profitability so as to produce attractive financial portfolios in the eyes of investors, with the creation of a good image in the financial portfolio it will be easy for companies to obtain sources of funds obtained including third party funds with competitive interest. This research aims to analyze the effect of working capital management on profitability and its impact on loan interest expense at PT. Bringin Karya Sejahtera through empirical studies in 2012 - 2016. The data collected is secondary data. Secondary data obtained from financial data of PT. Bringin Karya Sejahtera from $2012-2016$ is used as a research sample, various sources such as journals, books and other related publications. The research method of multiple regression analysis and panel funding analysis. The results showed simultaneously or partially Working Capital Management (Current Ratio, Debt to Assets Ratio, Receivable Turn Over and Working Capital Turnover) significantly influence Profitability (Return on Assets) and Loan Interest Rates, with R2 in the Analysis Panel showing that the influence of Management Working Capital through better profitability. Management of PT. Bringin Karya Sejahtera should pay attention to working capital management to increase profitability in order to get a good loan interest.
\end{abstract}

Keywords: Working Capital, Liquidity, Profitability, loan interest rate

\section{Introduction}

\subsection{Research Background}

Efficient working capital management is the answer to the problems that occur in managing current assets and current liabilities in companies. Working capital management will involve planning and controlling current assets and current liabilities in managing these current assets and liabilities. Working capital management strives to suppress and eliminate risks that arise in the form of the company's inability to fulfill its short-term obligations on the one hand and on the other hand to prevent the company from investing excessively. In achieving two main objectives, namely seeking profit and maintaining the company's life in a balanced manner, is a very difficult thing. The company certainly wants maximum profit so 
that the company can last a long time, but on the other hand, the company cannot ignore the liquidity of the company because if the company ignores it, the company may go bankrupt. It is clear from this section that the existence of working capital management is important. Working capital management can provide appropriate considerations regarding alternatives that will be used by the company and will later affect the company's profitability. The following is the initial data in the form of capital, profit and interest expense on loans from PT Bringin Karya Sejahtera:

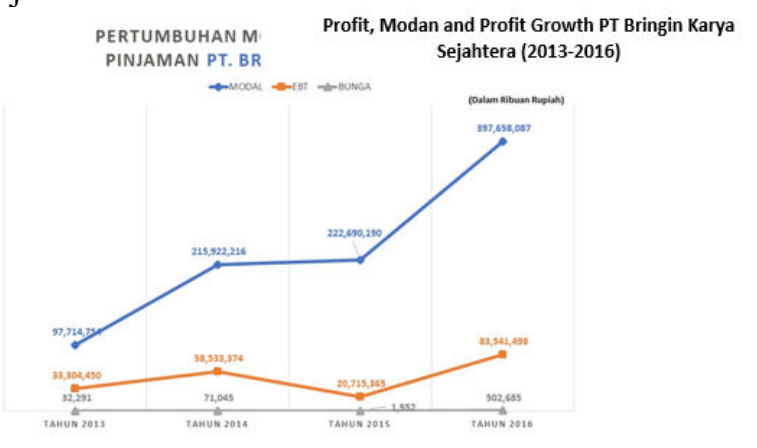

From the graph above, it can be seen that capital growth continues to increase every year, but the increase in capital each year is not followed by a linear increase in Profit (EBT), this can be seen in 2014 that there was an increase in Profit (EBT), but there was a decrease in Profit (EBT).) in 2015 even though it increased again in 2016, also with loan interest which has fluctuated growth from year to year. This is an odd thing because the increase in capital is not accompanied by an increase in profit as expected by the management of PT. BRIKS, even when the profit decreases, the loan interest decreases. Companies that have efficient working capital management can improve the company's ability to better manage current assets and current liabilities. When the company has a high production capability, it can provide sufficient funds and capital.

In working capital, companies must also manage trade receivables. Management must be able to make policies regarding accounts receivable collection. These policies can help companies collect their receivables on time[1]. Liquidity problems are related to the company's ability to meet its financial obligations that must be fulfilled immediately. The liquidity of a company shows the ability to pay short-term financial obligations on time. According to Agus Sartono [2], the proportion of use to finance investment or leverage means that companies that do not have leverage use their own capital $100 \%$. The use of debt itself for the company contains three dimensions (1) the credit provider will focus on the amount of collateral for the credit provided, (2) by using debt, if the company gets a greater profit than its fixed expenses, the owner of the company will increase its profits and (3) by using debt, the owner gets funds and does not lose control of the company.

Based on the background and phenomena described above, the need for research on the effect of working capital management on profitability and its impact on loan interest expense at PT. Bringin Karya Sejahtera Period.

\subsection{Research purposes}

This study aims to analyze the effect of working capital management (Current Ratio, Debt to Assets Ratio, Receivable Turn Over and Working Capital Turnover) on Profitability (Return on Assets) and its impact on the Loan Interest Rate. 


\subsection{Theoretical Framework and Hypotheses}

\subsubsection{Liquidity}

Lukman Syamsudin states that liquidity is an indicator of a company's ability to pay all short-term financial liabilities at maturity using available current assets[3]. Liquidity is not only concerned with the company's financial condition, but also with its ability to convert certain current assets into cash. According to Kasmir, the inability of companies to pay their obligations, especially short-term (which are due) is due to various factors [4], namely: (1) It could be because the company doesn't have any funds at all; (2) It could be that the company has funds, but at maturity the company does not have funds (not enough funds in cash so they have to wait a certain time, to disburse other assets such as collecting receivables, selling securities, or selling other assets). According to Mamduh the formula of liquidity ratio[5] :

$$
\text { Current Ratio }=\frac{\text { Current Assets }}{\text { Current Liabilities }}
$$

From the above understanding, it can be seen that a company can be said to be liquid if it can settle its short-term obligations which are due soon. In an effort to be able to meet these short-term obligations, the company must be able to provide sources of payments that can be realized immediately. The source of payment is obtained from the current assets owned by the company.

\subsubsection{Leverage}

The leverage ratio shows the proportion of the use of debt to finance the investment. Companies that do not have leverage means using their own capital 100\%. According to Agus Sartono the use of debt for companies contains three dimensions, namely [2]: (1) Creditors will focus on the amount of collateral for the credit provided; (2) By using debt, if the company gets a profit that is greater than its fixed expenses, the owner of the company will have an increased profit; (3) By using debt, the owner gets funds and does not lose control of the company. To calculate the amount of use of corporate debt, several leverage ratios can be used, according to Darsono and Ashari the types of leverage ratios are:

Debt to Assets Ratio is the ratio of total liabilities to assets. This ratio emphasizes the importance of debt financing by showing the percentage of the company's assets that are supported by debt. If DAR has decreased, this indicates that the company's performance is increasing with the decrease in the portion of debt in funding assets, besides it also shows that most of the investment is funded by own capital and also results in small interest payments. Having high leverage does not always mean bad, even leverage at a certain level can increase ROE but the problem is that excessive leverage will ultimately reduce profit margins and reduce asset turnover efficiency[6], DAR can be formulated as follows:

\subsubsection{Receivable Turnover}

$$
D A R=\frac{\text { Total of Liabilities }}{\text { Total of Asset }}
$$

Accounts receivable turnover is a ratio that shows the length of time to convert receivables into cash [7]. Accounts receivable round is calculated by dividing net credit sales by the average balance of accounts receivable. Receivables owned by a company have a close relationship with the volume of credit sales. The accounts receivable position can be calculated using the accounts receivable turnover ratio. Based on the definition above, what 
is meant by accounts receivable turnover is the ratio between credit sales that generate accounts receivable for the company and the average accounts receivable. Therefore, the accounts receivable turnover formula is formulated as follows:

$$
\text { Receivable Turn Over }=\frac{\text { Net Account Receivable x ....Time }}{\text { Average Account Receivable }}
$$

\subsection{Working Capital Turnover}

Working capital is a company investment in the form of current assets. The definition of working capital according to Bambang Riyanto states that the definition of working capital is intended as the total amount of current assets[7]. Working capital according to Agus Sartono states that there are two definitions of working capital, namely [2]: (1) Gross Working Capital is the total assets of ancer which is based on the amount or quantity of funds invested in the assets of ancer. Ancer assets are company assets whose physical form changes in a production process activity which runs out in one use and can be cashed in ancer in the short term, which is less than one year; (2) Net Working Capital is ancer's excess assets over current debt.

In this study, the authors use the turnover method to determine working capital turnover because this method uses analysis of the company's financial statements. Bambang Riyanto (formulates a formula for calculating Working Capital Turnover (WCT) as follows [7]:

$$
\text { WTC }=\frac{\text { Revenue }}{\text { Current Asset-Current Liabilities }}
$$

If the working capital turnover ratio is high, it will indicate low liquidity to support operations, whereas if this ratio is low, it indicates high liquidity. This working capital turnover shows the number of net sales rupiahs earned for each rupiah of working capital. From the relationship between net sales and working capital, it can also be seen whether the company works with high working capital or works with low working capital.

\subsection{Profitability}

According to Agus Sartono argues that profitability Profitability is the company's ability to earn profits in relation to sales, total assets and own capital [2]. Profitability is said to be good if it meets the expected profit target. Low profitability indicates that the company's management performance level is not good. Companies that have a loss or low level of profitability will have a bad impact on market reactions and will cause a decline in the performance appraisal of a company. The purpose of using the profitability ratio for the company, as well as for those outside the company according to Kasmir is as follows [4]: (1)

To measure or calculate the profit earned by the company in a certain period; (2) To assess the company's profit position in the previous year with current knowledge; (3) To assess the progress of profit over time; (4) To assess the amount of net profit after tax with own capital; (5) To measure the productivity of all company funds used both loan capital and own capital; (6) To measure the productivity of all company funds. In this study the authors use the profitability ratio, namely the rate of return on assets (Return on Assets), with a formula to calculate the rate of return on assets as follows:

$$
\text { Return on Assets }=\frac{\text { Earnings After Tax } \times 100 \%}{\text { Total Asset }}
$$




\subsection{Interest Rate}

In running its business, companies need funds from both inside and outside the company. When funds from within the company are insufficient, funds from outside the company are needed for the survival of the company. Companies that use funds from outside the company will provide remuneration, in the form of interest and dividends. If funds from outside the company in the form of loans are used to finance the company's day-to-day activities, the interest costs incurred are borne by income as an element of expenses outside the business (other expenses). Interest charging problems will arise if the loan is used to finance the procurement of fixed assets. The problem is, should the loan interest be capitalized into the cost of the fixed assets.

Today, there is no official regulation to capitalize interest expense or treat interest as a finance expense. Based on the basic concept of unified accounting adopted by PAI 1984, PAI 1984 adopts "entity theory". According to the basic concept of unity, interest on debt is treated as a distribution of profit, so that interest on debt cannot be presented as a deduction from operating income in the income statement. However, interest on debt must be treated as dividends, namely as a deduction for retained earnings (as a distribution of profits) in the statement of retained earnings.

In this study the authors use the Pincaman Interest Rate ratio, with the formula for calculating loan interest rates as follows:

\section{Loan interest expense: Third party loans payable $x 100 \% x$ loan period}

\subsection{Hypothesis Development and Thinking Framework}

Based on the theoretical review that has been previously presented, the research hypothesis is proposed as follows:

Hypothesis 1: There is an Influence of liquidity on profitability

Hypothesis 2: There is an Influence of leverage on profitability

Hypothesis 3: There is an Influence of Accounts Receivable Turnover on Profitability

Hypothesis 4: There is an Influence of working capital turnover on profitability

Hypothesis 5: There is an Influence of Liquidity, Leverage, Accounts Receivable Turnover, and Working Capital Turnover on Profitability

Hypothesis 6: There is a Profitability Effect on loan interest expenses

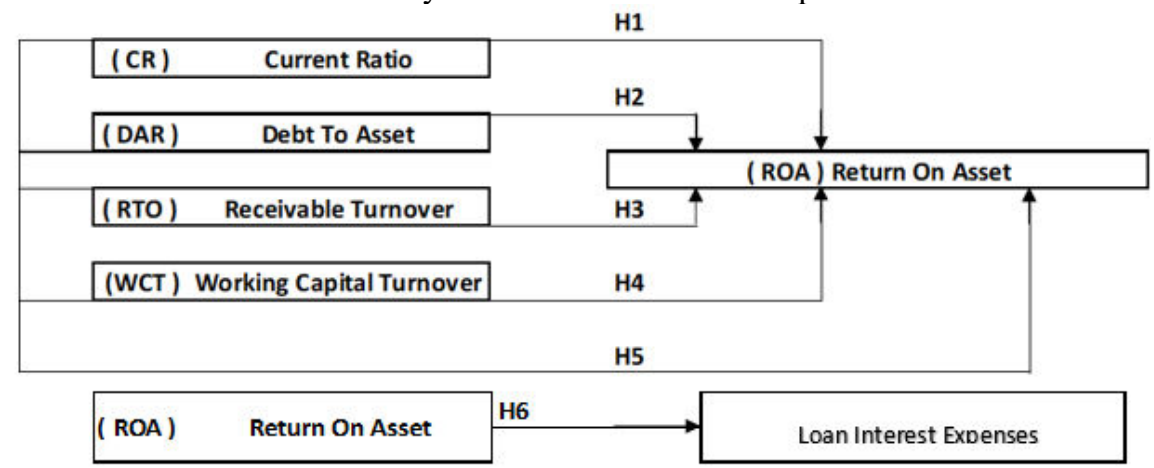

Fig 1. Framework of thinking 


\section{Research Method}

Quantitative research sees the relationship between variables and the object under study is more causal, so that in his research there are independent and dependent variables. Thus, this research can be categorized into types or quantitative causality research designs. In this case, the researcher wants to know the effect of Liquidity, Leverage, Accounts Receivable Turnover and Working Capital Turnover with statistical testing to find out the four variables on Profitability (ROA) and their impact on Loan Interest Expenses [8]. To test the effect of 3 independent variables and 2 dependent variables, the research instrument was taken, namely the financial data of PT. Bringin Karya is prosperous. Financial data is processed into financial ratios according to the research theme, the resulting ratios are Current Ratio, Debt to Asset Ratio, Receivable Turnover, Working Capital Turnover, Return on Assets and Loan Interest Rates taken in the 2012 - 2015 period.

\section{Results and Discussion}

\subsection{Classic assumption test \\ 3.1.1 Normality test}

Table 1. Normality Test of Current Ratio, Debt to Asset Ratio, Receivable Turnover, Working Capital Turnover, Return on Asset and Loan Interest Rate

One-Sample Kolmogorov-Smimov Test

\begin{tabular}{|ll|l|}
\hline & & $\begin{array}{l}\text { Unstandardize } \\
\mathrm{d} \text { Residual }\end{array}$ \\
\hline $\mathrm{N}$ & & 60 \\
Normal Parameters ${ }^{\mathrm{a} b \mathrm{~b}}$ & Mean & .0000000 \\
& Std. Deviation & .03851157 \\
Most Extreme Differences & Absolute & .071 \\
& Positive & .071 \\
& Negative & -.046 \\
Test Statistic & & .071 \\
Asymp. Sig. (2-tailed) & & $.200^{\mathrm{c}, \mathrm{d}}$ \\
\hline
\end{tabular}

a. Test distribution is Normal.

b. Calculated from data.

c. Lilliefors Significance Correction.

d. This is a lower bound of the true significance.

Sumber : Data Olahan Penelitian (2019)

From table 3.1 above, it can be seen that the data is normally distributed, this is because the results of the significance (Asymp.Sig) of the six variables are greater than 0.05 . In the output above, according to the Kolmogorov Smirnov $\mathrm{Z}$ method, the K-S Z value for the seven variables is 0.200 . 


\subsubsection{Multicollinearity Test}

Table 2. Multicollinearity Test Results Coefficients

\begin{tabular}{|c|c|c|c|c|}
\hline \multirow[b]{2}{*}{ Model } & \multicolumn{3}{|c|}{ Collinearity Statistics } & \multirow[b]{2}{*}{$\begin{array}{l}\text { Batas } \\
\text { VIF }\end{array}$} \\
\hline & Tolerance & $\begin{array}{l}\text { Batas } \\
\text { Tolerance }\end{array}$ & VIF & \\
\hline \multicolumn{5}{|l|}{ (Constant) } \\
\hline $\begin{array}{l}\text { Current Ratio } \\
\left(\mathrm{X}_{1}\right)\end{array}$ & 0,774 & 0,100 & 1,292 & 10 \\
\hline $\begin{array}{l}\text { Debt To Assets } \\
\text { Ratio }\left(\mathrm{X}_{2}\right)\end{array}$ & 0,860 & 0,100 & 1,162 & 10 \\
\hline $\begin{array}{l}\text { Receivable } \\
\text { Turn Over (X3) }\end{array}$ & 0,526 & 0,100 & 1,900 & 10 \\
\hline $\begin{array}{l}\text { Working } \\
\text { Capital } \\
\text { Turnover (X4) }\end{array}$ & 0,494 & 0,100 & 2,023 & 10 \\
\hline $\begin{array}{l}\text { Return } \\
\text { Asset (Y) }\end{array}$ & 0,559 & 0,100 & 1,789 & 10 \\
\hline
\end{tabular}

According to the multicollinearity test results in Table 3.2 above, the VIF for each of the five variables is $1.292,1.162,1,900,2.023$ and 1.789 in other words, VIF is less than 10. It can be concluded that there is no multicollinearity in the regression model with a tolerance value greater than 0.1 .

\subsubsection{Heteroscedasticity Test}
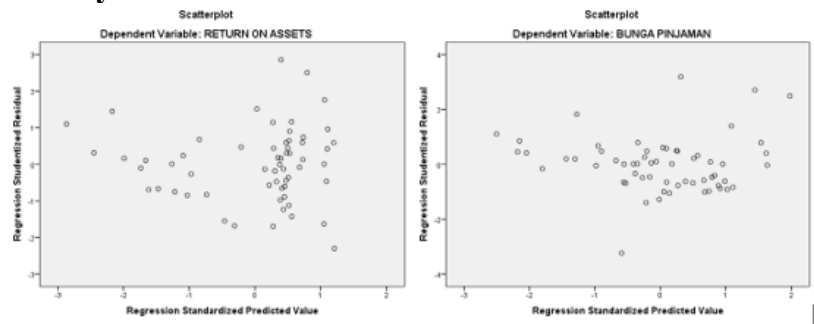

Fig 4. Heteroscedasticity Test Results

From Figure 4.1 it can be seen that the dots spread randomly, it can be concluded that there is no heteroscedasticity in the regression model. Then it can be concluded that the regression model qualifies for further analysis.

\subsection{Hypothesis Test Results}

\subsubsection{Multiple Regression}

The results of testing the variables Current Ratio, Debt to Asset Ratio, Receivable Turnover, Working Capital Turnover on Return on Assets in Table 4.3 are as follows:

Table. 3 Results of Testing the Effect of Current Ratio, Debt to Asset Ratio, Receivable

Turnover, Working Capital Turnover on Return on Assets

\begin{tabular}{lccc}
\hline Model & $\mathbf{B}$ & $\mathbf{t}_{\text {hitung }}$ & \multicolumn{1}{l}{ Sig. } \\
\hline (Constant) & 23,172 & 1,848 & 0,070 \\
Current Ratio & $-0,077$ & $-2,097$ & 0,041 \\
Debt To Assets Ratio & 0,094 & 2,814 & 0,015 \\
Receivable Turn Over & $-0,185$ & $-4,937$ & 0,000 \\
Working Capital Turnover & $-0,087$ & $-2,637$ & 0,011 \\
\hline
\end{tabular}


Based on Table 3.3 above, the coefficient values for each independent variable used can be determined as follows:

$$
R O A=23.172-0.077 C R+0.094 D A R-0.185 R T O-0,087 W C T
$$

The value of Constants a is equal to 23,172, this shows that if Current Ratio (CR), Debt to Asset Ratio (DAR), Receivable Turnover (RTO), Working Capital Turnover (WCT) each have a value of 0, then Return on Asset (ROA) worth 23,172, the value of Return On Asset shows that the level of performance is quite low, so it needs to be controlled using Current Ratio (CR), Debt to Asset Ratio (DAR), Receivable Turnover (RTO), Working Capital Turnover (WCT). The independent variable Current Ratio (CR) has a coefficient value of 0.077, which means that there is a negative effect of the Current Ratio (CR) variable on Return on Asset (ROA), if other independent variables are fixed and Current Ratio (CR) has increased or increased, then the variable Return on Asset (ROA) will decrease by 7.7\%.

The independent variable Debt to Assets Ratio (DAR), has a coefficient value of 0.094, meaning that there is a positive influence on the Debt to Assets Ratio (DAR) variable on Return on Asset (ROA), if other independent variables are fixed and the Debt to Assets Ratio (DAR) has increase or increase, then the variable Return on Assets (ROA) will increase by 9.7\%. The independent variable Receivable Turnover (RTO) has a coefficient value of 0.184 which means that there is a negative effect of Receivable Turnover (RTO) on Return on Asset (ROA), if the other independent variables are fixed and Receivable Turnover (RTO) has increased or increased, then the variable Return on assets (ROA) will decrease by $18.5 \%$. The independent variable Working Capital Turnover (WCT) has a coefficient value of -0.087 which means that there is a negative effect of Working Capital Turnover (WCT) on Return on Asset (ROA), if the other independent variables are fixed and Working Capital Turnover (WCT) has increased or increased, then the variable Return On Asset (ROA) will decrease by $8.7 \%$.

\subsubsection{Result of Determination Coefficient Test (R2)}

Table 4 Results of the Coefficient of Determination (R2) Model Summary ${ }^{b}$

\begin{tabular}{lllll}
\hline Model & R & R Square & $\begin{array}{l}\text { Adjusted } \\
\text { Square }\end{array}$ & $\begin{array}{l}\text { R } \\
\text { Std. Error of } \\
\text { the Estimate }\end{array}$ \\
\hline 1 & .651 & $\mathbf{0 . 4 2 3}$ & 0.381 & .04051 \\
\hline Dependent Variable: $:$ Retum & & &
\end{tabular}

Dept : Vata Olahan Penlitian (2019)

Based on Table 3.4 above, it shows that Current Ratio (CR), Debt to Asset Ratio (DAR), Receivable Turnover (RTO), Working Capital Turnover (WCT) to Return On Assets (ROA) is $42.3 \%$, while $57.7 \%$ explained by other factors.

\subsubsection{Result of Partial Regression Test (t-test)}

Table 5. Results of Partial Regression Test (t-test)

\begin{tabular}{lccc}
\hline Model & B & thitung & Sig. \\
\hline (Constant) & 23,172 & 1,848 & 0,070 \\
Current Ratio & $-0,077$ & $-2,097$ & 0,041 \\
Debt To Assets Ratio & 0,094 & 2,814 & 0,015 \\
Receivable Turn Over & $-0,185$ & $-4,937$ & 0,000 \\
Working Capital Turnover & $-0,087$ & $-2,637$ & 0,011 \\
\hline
\end{tabular}


The results of testing the research hypothesis in Table 4.5 The Summary of the Partial Regression Test (t-test) above are described as follows:

a. H1: Based on the value of the regression analysis, the significance value (sig.) Is 0.041 $<0.05$, it can be concluded that Ho is rejected and H1 is accepted. Thus, this hypothesis proves that "Current Ratio (CL) has a significant effect on Return on Assets (ROA)".

b. H2: Based on the value of the regression analysis, the significance value (sig.) Is 0.015 $<0.05$, it can be concluded that Ho is rejected and H2 is accepted. Thus, this hypothesis proves that "Debt to Assets Ratio (DAR) has a significant effect on Return on Assets (ROA)".

c. H3: Based on the value of the regression analysis, the significance value (sig.) Is 0.000 $<0.05$, it can be concluded that Ho is rejected and H3 is accepted. Thus, this hypothesis proves that "Receivable Turn Over (RTO) has a significant effect on Return on Assets (ROA)".

d. H4: Based on the value of the regression analysis, the significance value (sig.) Is 0.011 $<0.05$, it can be concluded that Ho is rejected and $\mathrm{H} 4$ is accepted. Thus, this hypothesis proves that "Working Capital Turnover (RTO) has a significant effect on Return on Assets (ROA)".

\subsubsection{Simultaneous Regression Test Results (F-Test)}

Table 6 Simultaneous Regression Test Results (F-Test)

\begin{tabular}{|c|c|c|c|c|c|}
\hline Model & $\begin{array}{l}\text { Sum of } \\
\text { Squares }\end{array}$ & Df & $\begin{array}{l}\text { Mean } \\
\text { Square }\end{array}$ & $\mathbf{F}$ & Sig. \\
\hline 1 Regression & .066 & 4 & .017 & 10.097717 &, $000^{\mathrm{b}}$ \\
\hline Residual & .090 & 55 & .002 & & \\
\hline Total & .157 & 59 & & & \\
\hline $\begin{array}{l}\text { a. Dependent V } \\
\text { b. Predictors: } \\
\text { Turn Over }\left(\mathrm{X}_{3}\right)\end{array}$ & $\begin{array}{l}\text { : Return On } \\
\text { ant), Current } \\
\text { sing Capital }\end{array}$ & Rati & t To & Ratio ( & Receivable \\
\hline
\end{tabular}

Source: Research Data (2019)

Based on the ANOVA test results in Table 4.6 ANOVA Test Results (F-Test) above, it can be seen that the significance value is 0.000 because the significance value is smaller than the alpha value of 5\%, in accordance with the basis for decision making in the F-test, it can be concluded that the variable Current Ratio (CR), Debt to Asset Ratio (DAR), Receivable Turnover (RTO), Working Capital Turnover (WCT) have a significant effect on Return On Asset (ROA) or it can be stated that H5 is accepted.

\subsubsection{Simple Regression}

\subsubsection{Regression}

The results of testing the variable Current Return on Asset to the Loan Interest Rate are in Table 4.7 as follows:

Table. 7 Results of Testing of Return On Assets to Loan Interest Rates.

\begin{tabular}{lccc}
\hline Model & B & thitung & Sig. \\
\hline (Constant) & 17,233 & 2.802 & .001 \\
ROA & 0,029 & 2.067 & .016 \\
\hline
\end{tabular}

Source: Research Data (2019) 
Based on Table 4.11 above, the coefficient values for each independent variable used can be determined as follows:

$$
L I R=17.233+0,029 R O A
$$

The value of Constants a is equal to 17,233 , this shows that if the Return on Asset is 0 , then the Loan Interest Rate (TBP) is 17,233, the Loan Interest Rate (LIR) is quite low, so it needs to be controlled using Return on Asset (ROA). The independent variable Return on Asset (ROA) has a coefficient value of 0.029 , which means that there is a positive influence on the variable Return on Asset (ROA). Loan Interest Rate (LIR), if the independent variable Return on Asset (ROA) increases or increases, the Loan Interest Rate (LIR) variable will decrease by $2.9 \%$.

\subsubsection{Result of Determination Coefficient Test (R2)}

Model Summary

Table 8 Results of the Coefficient of Determination (R2)

\begin{tabular}{lllll}
\hline Model & $\mathbf{R}$ & R Square & $\begin{array}{l}\text { Adjusted } \\
\text { Square }\end{array}$ & R $\begin{array}{l}\text { Std. Error of } \\
\text { the Estimate }\end{array}$ \\
\hline 1 & .219 & $\mathbf{0 . 0 4 8}$ & 0.032 & .0526 \\
\hline
\end{tabular}

Dependent Variable : Tingkat Bunga Pinjaman (Z)

Sumber : Data Olahan Penelitian (2019)

Source: Research Data (2019)

Based on Table 4:12 above, it shows that the Return on Assets (ROA) to the Loan Interest Rate (TBP) is $4.85 \%$, while $95.15 \%$ is explained by other factors.

3.2.2.3 Partial Regression Test Results (t-test)

Table 9 Results of Partial Regression Test (t-test)

\begin{tabular}{lccc}
\hline Model & B & thitung & Sig. \\
\hline (Constant) & 17,233 & 2.802 & .001 \\
ROA & 0,029 & 2.067 & .016 \\
\hline
\end{tabular}

Source: Research Data (2019)

H6: Based on the value of the regression analysis, the significance value (sig.) Is 0.016 $<0.05$, it can be concluded that Ho is rejected and H9 is accepted. Thus, this hypothesis proves that "Return on Assets (ROA) has a significant effect on the Loan Interest Rate (LIR)".

\section{Conclusions}

Current Ratio, Debt to Asset Ratio, Receivable Turnover, Working Capital Turnover have a significant effect on Return on Assets. Current Ratio, Debt to Asset Ratio, Receivable Turnover, Working Capital Turnover have a significant effect on the Loan Interest Rate. Current Ratio, Return on Assets have a significant effect on the Loan Interest Rate. Therefore, the Management of PT. Bringin Karya Sejahtera must pay attention to Current Ratio, Debt to Asset Ratio, Receivable Turnover, Working Capital Turnover to increase 
profitability as well as maintain loan interest rates. In addition, Return on Asset is also a very important concern as a basis for a good image to get an ideal loan interest rate from investors.

Based on the above analysis, the current ratio has a significant effect on return on assets at PT. Bringin Karya Sejahtera. This is in line with the research of Mokhamad Setiadi, M. Noor Salim in 2018 on the BUMN Stock Exchange Listed in Bei for the 2013-2016 Period, which states that partially the current ratio has a significant effect on return on assets [9]. Therefore, the current ratio, which means the company's ability to meet short-term obligations, must be considered by PT. Bringin Karya Sejahtera in order to drive its Return on Assets to match the expectations of management. Then there is a significant influence between the Debt to Assets Ratio to Return on Assets. This is in line with the research of Herman Supardi, H. Suratno and Suyanto Suyanto in 2018 at the Cooperative in Indramayu Regency, which states that partially the debt to asset ratio has a significant effect on return on assets [10]. Therefore, the Debt to Assets Ratio which means the composition of assets funded by debt must be considered by PT. Bringin Karya Sejahtera in order to mobilize its Return on Assets to match the expectations of management.

Partially there is a significant effect between Receivable Turn Over and Return On Assets. This is in line with Sri Rahayu and Eric 2014 research on food and beverage companys registered on BEI 2008-2012, which states that partially receivable turnover has a significant effect on return on assets [11]. Therefore, Receivable turnover, which means the fulfillment of receivables into cash must be considered by PT. Bringin Karya Sejahtera in order to move its Return on Assets to match the expectations of management, because the lower the Receivable turnover will accelerate the realization of Return on Assets. It can be seen that there is a significant influence between Working Capital Turn Over on Return On Assets. This is in line with the research of Migang in 2019 on Ceramic Companies Listed on the Indonesia Stock Exchange, which states that working capital turnover has a significant effect on return on assets [12]. Therefore, working capital turnover, which is working capital used as a business activity, must be considered by PT. Bringin Karya Sejahtera in order to mobilize its Return on Assets to match the expectations of management.

Simultaneously it can be stated that Current Ratio (CR), Debt to Assets Ratio (DAR), Receivable Turn Over (RTO), Working Capital Turnover (WCT) have a significant effect simultaneously on Return on Assets (ROA). Then partially there is a significant influence between Receivable Turn Over on the Loan Interest Rate. Therefore, Receivable turnover, which means the fulfillment of receivables into cash must be considered by PT. Bringin Karya Sejahtera in order to reduce the loan interest rate. This research was conducted only on Current Ratio (CR), Debt to Assets Ratio (DAR), Receivable Turn Over (RTO), Working Capital Turnover (WCT), Return on Asset (ROA) and Loan Interest Rate (TBP) of PT. Bringin Karya Sejahtera for the period 2012 - 2015. Further research can explore other independent variables that have not been examined in this study, namely other ratios of working capital, liquidity, profitability and interest rates.

\section{References}

[1] V. H. J. C and W. J. M, Prinsip-Prinsip Manajemen Keuangan, 13th ed. Jakarta: Salemba Empat, 2013.

[2] S. Agus, Manajemen Keuangan teori dan aplikasi (edisi 4), 4th ed. Yogyakarta: BPFEYOGYAKARTA, 2001.

[3] Syamsuddin;Lukman, Manajemen Keuangan Perusahaan. Jakarta: Rajawali Pers, 2011.

[4] Kasmir, Manajemen Perbankan, Revisi. Jakarta: Rajawali Pers, 2012.

[5] M. M. Hanafi and H. Abdul, Analisis Laporan Keuangan, 7th ed. Yogyakarta: UPP STIM 
YKPN, 2014.

[6] Darsono and Ashari, Pedoman Praktis Memahami Laporan Keuangan. Yogyakarta: Salemba Empat, 2005.

[7] R. Bambang, Dasar- Dasar Pembelanjaan Perusahaan, 4th ed. Yogyakarta: YBPFE UGM, 2011.

[8] Sugiyono, Metode Penelitian Kuantitatif Kualitatif dan R\&D, 2016th ed. Bandung: Alfabeta, 2016.

[9] M. Setiadi and M. N. Salim, "FAKTOR FUNDAMENTAL DAN PENGARUHNYA TERHADAP HARGA SAHAM BUMN YANG TERDAFTAR DI BEI PERIODE TAHUN 2013 - 2016,” Indik. J. Ilm. Manag. dan Bisnis UMB, vol. 2, no. 2018, p. 29, 2018.

[10] H. Supardi, H. S. H. Suratno, and S. Suyanto, "PENGARUH CURRENT RATIO, DEBT TO ASSET RATIO, TOTAL ASSET TURNOVER DAN INFLASI TERHADAP RETURN ON ASSET," JIAFE (Jurnal Ilm. Akunt. Fak. Ekon., vol. 2, no. 2, pp. 16-27, Mar. 2018, doi: 10.34204/jiafe.v2i2.541.

[11] E. P. Naibaho and S. Rahayu, "INFLUENCE OF RECEIVABLES TURNOVER AND INVENTORY TURNOVER TO PROFITABILITY (EMPIRICAL STUDY OF FOOD AND BEVERAGE COMPANY LISTED IN BEI 2008-2012)," e-Proceeding Manag., vol. 1, no. 2014, p. 279, 2014.

[12] S. Migang and A. Irawan, "Pengaruh Cash Turnover, Working Capitalturnover, Receivable Turnover, Dan Inventory Turnover Terhadap Return On Asset Pada Perusahaan Keramik Yang Terdaftar Di Bursa Efek Indonesia,” J. GeoEkonomi, vol. 10, no. 2, pp. 219-238, Sep. 2019, doi: 10.36277/geoekonomi.v10i2.60. 